\title{
Erratum
}

\section{Protection without Discrimination: Pregnancy and Occupational Health Regulations - ERRATUM}

\author{
Sven Ove HANSSON and Linda SCHENK
}

DOI: 10.1017/S1867299X00005808 Published online: 20 January 2017

In the above mentioned article [1] the author's name was incorrect. It was originally given as Sven Hove Hansson but it has now been corrected to Sven Ove Hansson.

\section{REFERENCES}

[1] SO Hansson and L Schenk. "Protection without Discrimination: Pregnancy and Occupational Health Regulations". (2016) 7(2) European Journal of Risk Regulation 404-412. doi: 10.1017/S1867299X00005808. 